\title{
The effect of citrates and sulfates of different metals on the biomass composition of medicinal mushroom Trametes versicolor (L.) Lloyd.
}

\author{
GALEB ADNANOVYCH AL-MAALI \\ NINA ANATOLIIVNA BISKO \\ ANDRIY MYKOLAIOVYCH OSTAPCHUK
}

Al-MaAli G.A., BiSKO N.A., OSTAPCHUK A.M. (2016). The effect of citrate and sulfate of different metals on the biomass composition of medicinal mushroom Trametes versicolor (L.) Lloyd. Chornomors'k. bot. z., 12 (1): 64-71. doi:10.14255/23089628/16.121/6.

\begin{abstract}
A comparative study has been carried out on the impact of citrate and sulfate of zinc and manganese on the biomass composition of mycelium of medicinal mushroom Trametes versicolor 353 cultivated in a liquid media. It was demonstrated that sulfates and citrates of studied metals have different effects on the mycelial growth and some biochemical parameters. Sulfates and citrates of these metals influence to different degrees on the amount of some amino acids in the mycelium of $T$. versicolor 353. Also citrates of both metals decrease amount of cis-linoleic acid (C18:2) relative to the control medium and medium with sulfate of appropriate metals.
\end{abstract}

Key words: Trametes versicolor, citrate, sulfate, zinc, manganese, amino acids, fatty acids

АЛЬ-МААЛІ Г.А., БІСЬКО Н.А., ОСТАПЧУК А.М. (2016). Вплив цитратів и сульфатів різних металів на склад біомаси лікарського гриба Trametes versicolor (L.) Lloyd. Чорноморськ. бот. ж., 12 (1): 64-71. doi:10.14255/2308-9628/16.121/6.

В статті наведені дані дослідження впливу цитратів та сульфатів марганцю та цинку на біохімічний склад біомаси цінного лікарського гриба Trametes versicolor 353 , що зростав на рідкому живильному середовищі в умовах глибинної культури. Результати експерименту свідчать про те, що цитрати та сульфати цих металів впливають різним чином на склад біомаси $T$. versicolor 353. Встановлено, що цитрати та сульфати обох досліджених металів у різній мірі змінюють концентрацію певних амінокислот в міцелії. Наявність цитрату цинку чи марганцю у живильному середовищі зменшувало вміст цис-лінолевої кислоти в біомасі $T$. versicolor 353, порівняно з сульфатами відповідних металів та контрольним середовищем без досліджуваних елементів.

Ключові слова: Trametes versicolor, циитрат, сульфат, цฺинк, марганецьь, амінокислоти, жирні кислоти

АЛЬ-МААЛИ Г.А., БИСЬКО Н.А., ОСТАПЧУК А.Н. (2016). Влияние цитратов и сульфатов различных металлов на состав биомассы лекарственного гриба Trametes versicolor (L.) Lloyd. Черноморск. бот. ж., 12 (1): 64-71. doi:10.14255/2308$9628 / 16.121 / 6$.

В статье приведены результаты сравнительного исследования влияния цитратов и сульфатов марганца и цинка на биохимический состав биомассы ценного лекарственного гриба Trametes versicolor 353, выращенного на жидкой питательной среде в условиях глубинной культуры. В ходе эксперимента было показано, что цитраты и сульфаты исследованных металлов имеют различное влияние на состав биомассы T. versicolor 353. Установлено, что цитраты и сульфаты обоих металлов в разной степени воздействовали на содержание ряда аминокислот в мицелии T. versicolor 353. Наличие цитрата цинка или марганца в среде уменьшало содержание цис-линолевой кислоты в биомасcе $T$. versicolor 353 в сравнении с сульфатами соответствующих металлов и контрольной средой, не содержащей исследованный элемент.

Ключевые слова: Trametes versicolor, циитрат, сульфат, циинк, марганец, аминокислотьл, жирнье кислотьл 


\section{Introduction}

Higher basidiomycetes of the genus Trametes have numerous medicinal properties including antitumor, antibiotic, hepatoprotective and anti-virus properties [CAI..., 2010; MAEHARA..., 2012; PATEL, 2012]. The long history of use of these fungi in traditional oriental medicine is to treat inflammation of the upper respiratory tract, urinary system and digestive channel. It confirms their safety for human health. There are known products of medical purpose of genus of Trametes consisting of purified polysaccharide fractions and proteins [STANDISH..., 2008; ZONG..., 2012; KUAN..., 2013]. Moreover, T. versicolor has been used as an excellent source for lignocellulose degrading enzymes, such as laccase and Mn-peroxidase.

Modern industrial cultivation of medicinal xylotrophic basidiomycetes is directed at optimization of the process of their cultivation to increase the yield of biomass and biologically active substances. Growing the mycelium of fungus on synthetic liquid nutrient media gives the opportunity to change and modify the mineral composition of the culture substance, and thereby, affecting the biomass growth and synthesis of biologically active substances. A number of authors noted that some trace elements, including zinc and manganese, have a positive effect on biosynthesis of intracellular and extracellular polysaccharides [ZOU, 2005; XIAO..., 2006; ZHI-LING, 2009], gene expression of laccase [SODEN, DOBSEN 2001; VASINA..., 2015] and amino acids composition [ZoU, 2005] in some medicinal mushrooms. It should be noted, the special role of zinc in many key metabolic pathways including synthesis of amino acids, metabolism of RNA and DNA, signal transduction, and gene expression. Zinc is the only metal which appears in all enzyme classes [BROADLEY..., 2007]. Manganese is an important metal for mushrooms physiology, being absolutely necessary for metabolism and the antioxidant system. The classes of enzymes that have manganese cofactors are very broad, and include oxidoreductases, transferases, hydrolases, lyases, isomerases and ligases.

As a rule, inorganic metal salts are used in the culture medium for growth of fungi mycelium. However, aforementioned inorganic salts have several disadvantages, amongst which should be mentioned their low chemical purity and lower bioavailability as compared to the organic metallic compounds. In this sense, the most prospective are the salts of carboxylic acids, including metal citrates, which are allowed for use in the food industry.

Previously, we studied the effect of citrate and sulfate of different metals on mycelial growth of $T$. versicolor 353 [AL-MAALI, 2015]. The results obtained indicate the concentration of $1 \mathrm{mg} / \mathrm{L}$ of manganese and zinc (citrate form) was optimal for mycelial biomass synthesis relative to the control medium without investigated metals. The increased the biomass was $28.9 \%$ (medium with manganese citrate) and $36.7 \%$ (medium with zinc citrate).

The aim of our research was to study the influence of citrate and sulfate of manganese and zinc on the biomass composition of medicinal mushroom Trametes versicolor.

\section{Strain and cultural conditions.}

\section{Materials and Methods}

The studied strain of Trametes versicolor 353 was obtained from the Culture Collection of Mushrooms (IBK) from M.G. Kholodny Institute of Botany, National Academy of Sciences of Ukraine, Kyiv [BUCHALO..., 2011]. The selection of the strain was based on biotechnological investigations of Antonenko [ANTONENKO, 2013].

Zinc citrate and manganese citrate was obtained from Institute nanobiotechnologies and resource conservation of Ukraine, Kyiv.

In this study we used glucose-peptone-yeast extract medium (GPY) with a following composition of $(\mathrm{g} / \mathrm{L})$ : glucose - 25; peptone -3 ; yeast extract $-3 ; \mathrm{K}_{2} \mathrm{HPO}_{4}-1 ; \mathrm{KH}_{2} \mathrm{PO}_{4}-1$; $\mathrm{MgSO}_{4} \cdot 7 \mathrm{H}_{2} \mathrm{O}-0,25$; distilled water $-1000 \mathrm{ml}$; $\mathrm{pH} 6,5$ (control medium). $\mathrm{Mn}^{2+}$ or $\mathrm{Zn}^{2+}$ 
(sulfare form or citrate form) were added to control medium in concetration $1 \mathrm{mg} / \mathrm{L}$. Mycelium was grown in a submerged culture on a rotary shaker $(120 \mathrm{rpm})$ at $26^{\circ} \mathrm{C}$ in $250 \mathrm{ml}$ Erlenmeyer flasks, containing $50 \mathrm{ml}$ of liquid media. Inoculum obtained under similar conditions in 5 days. We used $5 \mathrm{ml}$ of inoculum for inoculation flasks with liquid medium.

Determination of dry weight and content of total nitrogen, crude protein, lipids, total carbohydrates and ash.

The biomass was harvested after 9 days of cultivation in the liquid medium, filtered, washed, dried to a constant weight at $105{ }^{\circ} \mathrm{C}$ and weighted. Total nitrogen content $\left(\mathrm{N}_{\text {total }}\right)$ in the mycelium determined by Kjeldahl method, crude protein content was determined as $\mathrm{N}_{\text {total }}$ x 6.25 [AOAC, 1995]. The ash was obtained by the standard method [AOAC, 1995]. Lipids were extracted from undried mycelium by a modified method of Bligh and Dyer [MANIRAKIZA..., 2001]. Amount of total carbohydrates was calculated, using the following formula:

$$
M_{c}=M_{b}-\left(M_{c p}+M_{l}+M_{a}\right)
$$

Where $\mathrm{M}_{\mathrm{c}}$ - weight of total carbohydrates, $\mathrm{g} / \mathrm{l} ; \mathrm{M}_{\mathrm{b}}$ - weight of biomass; $\mathrm{M}_{\mathrm{cp}}$ - weight of crude protein, $\mathrm{g} / \mathrm{l} ; \mathrm{M}_{1}-$ weight of lipids, $\mathrm{g} / \mathrm{l} ; \mathrm{M}_{\mathrm{a}}-$ weight of ash, $\mathrm{g} / \mathrm{l}$.

\section{Amino Acid Detection Method}

Amino acid composition was analyzed by high-performance liquid chromatography after derivatization with 9-fluorenylmethyloxycarbonyl chloride and o-phthalic anhydride.

Sample preparation: $0.1 \mathrm{~g}$ of the mycelium was placed in vial and $2 \mathrm{~mL}$ of $6 \mathrm{~N} \mathrm{HCl}$ were added. Hydrolysis was carried out for 24 hours at $110^{\circ} \mathrm{C} .0 .5 \mathrm{~mL}$ of hydrolyzate obtained from centrifugation was evaporated and washed by distilled water 3 times. After evaporation, the extract was dissolved with $0.5 \mathrm{~mL}$ of distilled water and filtrated with $0.2 \mu \mathrm{m}$ regenerated cellulose filter membrane. Obtainment of fluorescent derivative was carried out by an automatic programed procedure before the samples were inserted in chromatography column.

The conditions for detection of amino acids were as follows: high-performance liquid chromatograph Agilent 1200 (Agilent technologies, USA); chromatography column: Zorbax AAA, $150 \mathrm{~mm} \times 4,6 \mathrm{~mm} \times 3 \mu \mathrm{m}$; Mobile phase A: $40 \mathrm{mM} \mathrm{Na}_{2} \mathrm{HPO}_{4} \mathrm{pH} 7.8 ; \mathrm{B}-$ acetonitrile:methanol:water $(45: 45: 10, \mathrm{v} / \mathrm{v} / \mathrm{v})$; temperature of column thermostat is $40^{\circ} \mathrm{C}$. Detection of derivatized amino acids was implemented using fluorescence detector. Identification of amino acids was performed by comparing the retention times with a mix of standard amino acids (Agilent 5061-3334) [HENDERSON..., 2000; JAMBOR, MOLNAR-PERL, 2009A; JAMBOR, MOLNAR-PERL, 2009B].

\section{Fatty Acids Detection Method}

The methyl ethers of fatty acids were obtained by a standard method [CHRISTIE, 1989]. The methyl ethers of fatty acids were determined by gas chromatography-mass spectrometry (GC/MS) Agilent 6890N/5973 inert. chromatography column: HP-5MS, 30m $\times 0.25 \mathrm{~mm} \times$ $0.25 \mu \mathrm{m}$.

Chromatographic conditions: the carrier gas was helium at a flow rate of $1 \mathrm{~mL} / \mathrm{min}$. The injector was kept at $250^{\circ} \mathrm{C}$. The temperature gradient was $150-250^{\circ} \mathrm{C}$, at the rate of $40 \mathrm{C} / \mathrm{min}$.

Mass spectrum conditions: ion source: electron ionization (EI); electric energy: $70 \mathrm{eV}$; chromatogram was obtained by SCAN mode in the range of $40-700 \mathrm{~m} / \mathrm{z}$. The identification of the components of the studied samples was performed using the library of mass spectra NIST 02 and standard mix of methyl esters of fatty acids (Supelco, USA). Amount of each fatty acid was calculated as a percentage of total fatty acids.

\section{Statistical analysis}

Values are mean of three independent experiments done in triplicate and are expressed as mean \pm errors. Data were statistically analyzed by t test using OriginPro 8.5.1, Origin-Lab Corportion, USA. Differences between means at $5 \%(\mathrm{p}<0,05)$ level were considered to be significant. 


\section{Biochemical composition of biomass.}

\section{Results and Discussion}

Analysis of the main components of the biomass showed the following changes. Zinc and manganese in both forms (sulfate and citrate) equally affected the content of crude protein, carbohydrate and ash in the mycelium. In these trials, carbohydrate content in mycelium was reduced by approximately $4 \%$ relative to the control medium without zinc or manganese respectively (table 1). The percentage of ash in T. versicolor 353 mycelium on all media with zinc or manganese increased relative to the control medium by about one-third (table 1). Also in all trials, we detected slight increment of crude protein (table 1). It is likely, this effect is due to the action of metals ions.

At the same time, the presence of manganese citrate $\left(\mathrm{Mn}^{2+} 1 \mathrm{mg} / \mathrm{L}\right)$ on the GPY medium increased the total content of lipids in the mycelium (approximately twice relative to control medium without manganese and relative to medium with manganese sulfate). While the both forms of zinc (citrate and sulfate) increased the total content of lipids in the mycelium of $T$. versicolor 353 (table 1).

So, in the case of lipids our results demonstrate, that biological activity of manganese citrate is higher than activity of manganese sulfate.

\section{Amino acids content.}

We detected 16 amino acids on the T. versicolor 353 biomass (fig. 1, 2).

Amino acids composition of the mycelium depends on the occurrence of zinc or manganese (sulfate or citrate form) in the medium. It is necessary to note, that citrate and sulfate form of investigated metals modified amino acid composition of the mycelium differently.

Table 1

The influence of citrate and sulfate of zinc and manganese on the biomass production and biochemical parameters of $T$. versicolor 353 on GPY medium

Таблиця 1

Вплив цитратів та сульфатів цинку та марганцю на синтез біомаси $T$. versicolor 353 та її біохімічні склад на ГПД середовищі

\begin{tabular}{|l|l|l|l|l|l|}
\hline Parameters & $\begin{array}{l}\text { Control } \\
\text { medium }\end{array}$ & Zinc citrate & Zinc sulfate & $\begin{array}{l}\text { Manganese } \\
\text { citrate }\end{array}$ & $\begin{array}{l}\text { Manganese } \\
\text { sulfate }\end{array}$ \\
\hline Biomass, g/l & $4,77 \pm 0,21$ & $6,52 \pm 0,03$ & $5,79 \pm 0,23$ & $6,15 \pm 0,23$ & $5,05 \pm 0,32$ \\
\hline Increment of biomass, \% & 0,00 & 36,69 & 21,38 & 28,93 & 5,87 \\
\hline Crude protein, \% biomass & $17,56 \pm 0,31$ & $19,00 \pm 0,45$ & $18,37 \pm 0,22$ & $18,69 \pm 0,32$ & $19,00 \pm 0,27$ \\
\hline $\begin{array}{l}\text { Total carbohydrates, \%o } \\
\text { biomass }\end{array}$ & 75,02 & 70,55 & 71,15 & 71,09 & 71,82 \\
\hline Total lipids, \% biomass & $1,29 \pm 0,11$ & $2,31 \pm 0,23$ & $2,18 \pm 0,018$ & $2,32 \pm 0,18$ & $1,13 \pm 0,09$ \\
\hline Ash, \% biomass & $6,13 \pm 0,20$ & $8,14 \pm 0,36$ & $8,30 \pm 0,41$ & $7,90 \pm 0,34$ & $8,05 \pm 0,29$ \\
\hline
\end{tabular}

Table 2

The influence of citrate and sulfate of zinc and manganese on the amino acids content in mycelium of T. versicolor 353 on GPY medium

Таблиця 2

Вплив цитратів та сульфатів цинку та марганцю амінокислотний склад міцелію

T. versicolor 353 на ГПД середовищі

\begin{tabular}{|l|c|c|c|c|c|}
\hline \multicolumn{1}{|c|}{ Fatty acids } & $\begin{array}{c}\text { Control } \\
\text { medium }\end{array}$ & Zinc citrate & Zinc sulfate & $\begin{array}{c}\text { Manganese } \\
\text { citrate }\end{array}$ & $\begin{array}{c}\text { Manganese } \\
\text { sulfate }\end{array}$ \\
\hline Pentadecanoic acid (15:0) & $0,97 \pm 0,24$ & $0,79 \pm 0,14$ & $0,73 \pm 0,20$ & $1,0 \pm 0,24$ & $1,95 \pm 0,28$ \\
\hline Palmitoleic acid (C16:1) & $1,32 \pm 0,23$ & $0,47 \pm 0,07$ & $0,39 \pm 0,03$ & $1,73 \pm 0,26$ & $1,8 \pm 0,32$ \\
\hline Palmitic acid (C16:0) & $22,01 \pm 1,45$ & $20,39 \pm 1,97$ & $20,65 \pm 1,21$ & $19,09 \pm 1,48$ & $19,04 \pm 2,03$ \\
\hline Margaric acid (C17:0) & $0,54 \pm 0,17$ & $0,38 \pm 0,11$ & $0,36 \pm 0,13$ & $0,34 \pm 0,09$ & $0,35 \pm 0,13$ \\
\hline $\begin{array}{c}\text { cis- Linoleic acid } \\
\text { (C18:2) }\end{array}$ & $67,27 \pm 2,56$ & $57,99 \pm 2,1$ & $63,79 \pm 2,44$ & $61,64 \pm 1,7$ & $64,15 \pm 2,02$ \\
\hline Oleic acid (C18:1) & $3,36 \pm 0,87$ & $8,76 \pm 1,01$ & $6,74 \pm 0,79$ & $7,11 \pm 0,49$ & $6,33 \pm 0,56$ \\
\hline $\begin{array}{c}\text { trans- Linoleic acid } \\
\text { (C18:2). }\end{array}$ & $0,66 \pm 0,41$ & $5,57 \pm 0,74$ & $3,73 \pm 0,54$ & $4,05 \pm 0,48$ & $3,56 \pm 0,51$ \\
\hline Stearic acid (C18:0) & $1,74 \pm 0,10$ & $1,03 \pm 0,09$ & $1,12 \pm 0,23$ & $0,68 \pm 0,18$ & $0,76 \pm 0,10$ \\
\hline
\end{tabular}


In the trial with citrate and sulfate of zinc both compounds influenced to different degrees on the amount of L-serine, L-glycine and L-lysine. Thus, the quantity of L-serine in mycelium on GPY-zinc sulfate medium was increased by $47.9 \%$ and on GPY-zinc citrate medium by $55.8 \%$ relative to the control medium (fig. 1 ). The quantity of L-glycine in mycelium was increased by $23.5 \%$ (GPY-zinc citrate medium) and by $13.2 \%$ (GPY-zinc sulfate medium) relative to the control medium (fig. 1). Also concentration of L-lysine in mycelium of $T$. versicolor 353 was reduced by $19.4 \%$ on GPY-zinc citrate medium and $12.4 \%$ GPY-zinc sulfate medium in relationship to the control medium (Fig. 1). In the same time, citrate and sulfate forms equally decreased the amount of L-aspartic acid, L-histidine, Lthreonine, L-arginine, L-tyrosine, L-leucine respective to the control medium (fig. 1). And the amount of L-proline and L-methionine was equally grown up in both cases (zinc sulfate and zinc citrate).

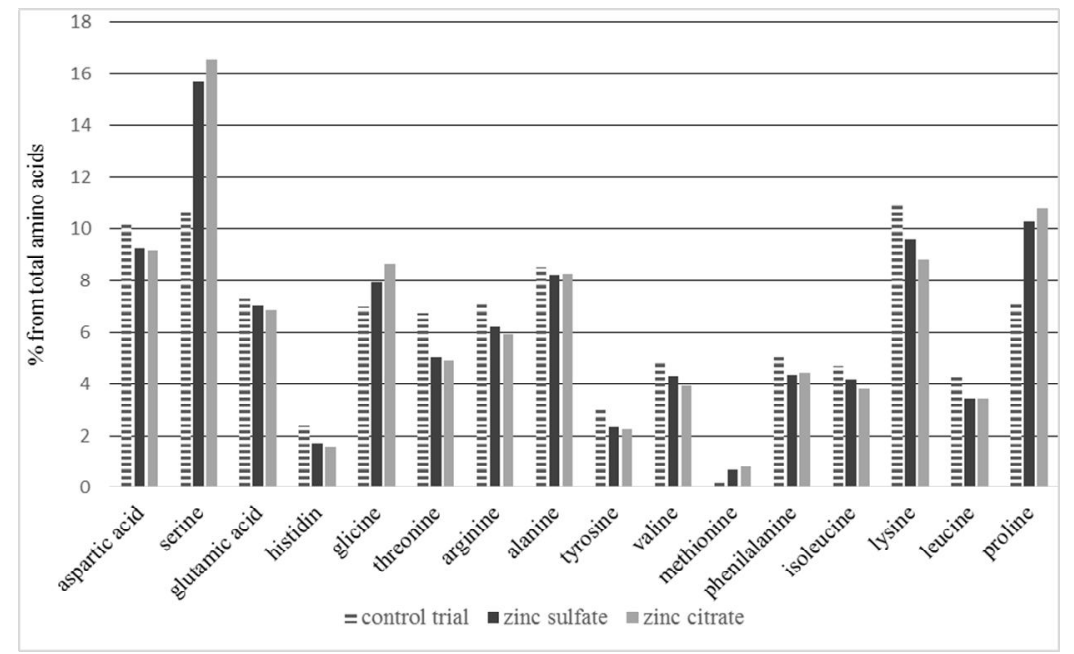

Fig. 1. Amino acids composition of $T$. versicolor 353 on GPY medium with zinc sulfate or zinc citrate.

Рис. 1. Амінокислотний склад біомаси T. versicolor 353 на ГПД середовищі з сульфатом цинку або цитратом цинку.

In the trial with citrate and sulfate of manganese both compounds influenced to different degrees on the amount of L-serine, L-lysine, L-proline. Thus manganese sulfate and manganese citrate increased the quantity of L-serine in mycelium of $T$. versicolor 353 by $57.3 \%$ and $69.6 \%$ respectively relative to the control medium (fig. 2). The quantity of Lproline in mycelium was increased by $41.9 \%$ (GPY- manganese citrate medium) and by $32.3 \%$ (GPY- manganese sulfate medium) relative to the control medium (fig. 2). In the same time, concentration of L-lysine was reduced by $22.4 \%$ (GPY- manganese citrate medium) and $16.8 \%$ (GPY - manganese sulfate medium) in relationship to the control medium. Only manganese sulfate have the positive effect on the amount of L-methionine (fig. 2). Thus, the content of L- methionine in the mycelium on GPY- manganese sulfate medium was increased 5.4 times as opposed to zinc citrate, which did not affect the amount of L- methionine. In the same time, both forms of manganese have the same effect on the amount of L-glycine, Lhistidine, L-threonine, L-arginine, L-tyrosine, L-leucine respective to the control medium (fig. 2).

But the amount of total essential amino acids in the mycelium was decreased on all trial by $5-8 \%$ respective to the control medium. 


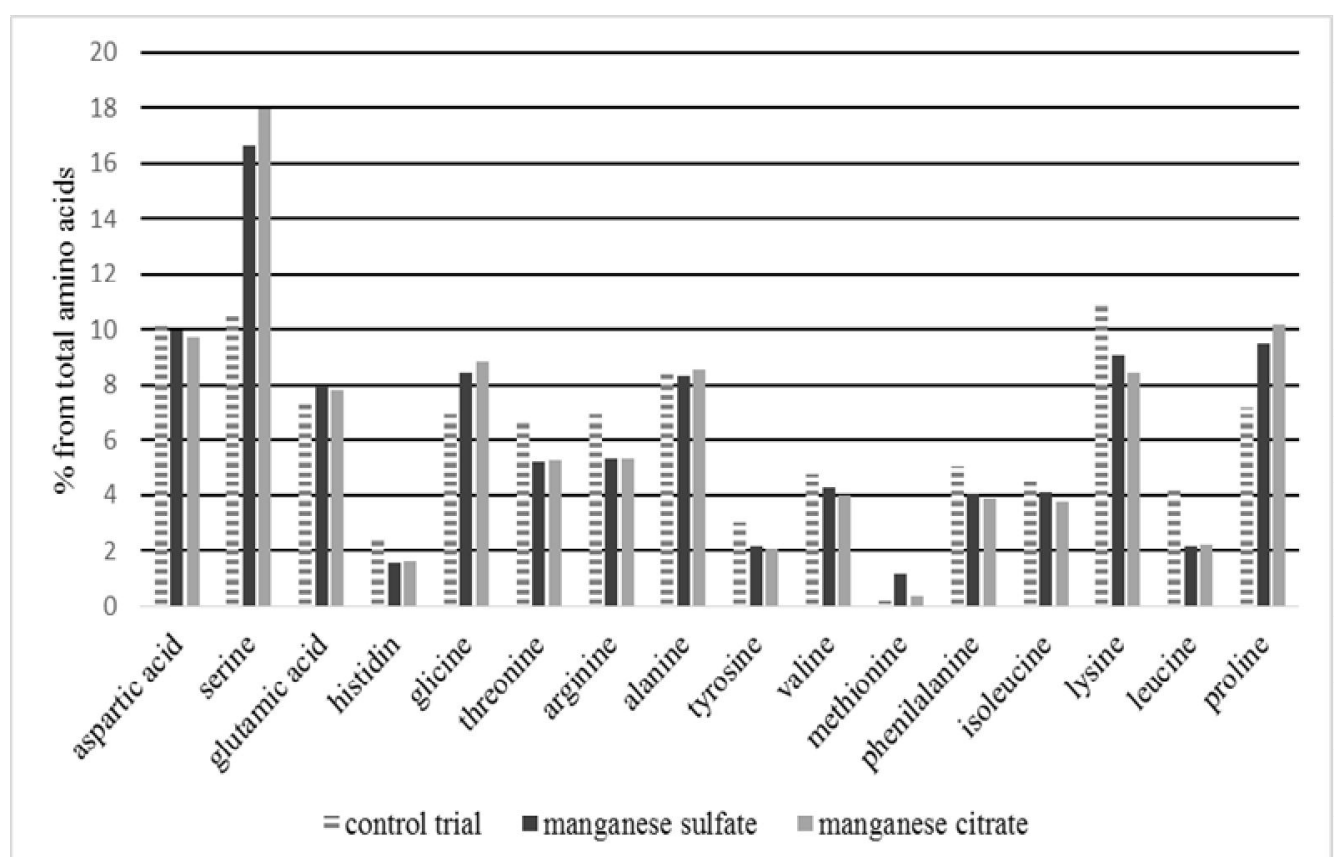

Figure 2. Amino acids composition of $T$. versicolor 353 on GPY medium with manganese sulfate or manganese citrate.

Рис. 2. Амінокислотний склад біомаси T. versicolor 353 на ГПД середовищі 3 сульфатом марганцю або цитратом марганцю.

Fatty acids content.

We detected 9 fatty acids on the $T$. versicolor 353 biomass: myristic acid (C14:0), pentadecanoic acid (15:0), palmitic acid (C16:0), palmitoleic acid (C16:1), margaric acid (C17:0), stearic acid (C18:0), oleic acid (C18:1), cis- and trans- form of linoleic acid (C18:2).

Both forms of manganese and zinc increased the amount of oleic acid (C18:1) and translinoleic acid (C18:2) and decreased the amount of stearic acid (C18:0). In the same time, in both cases, as with zinc citrate and manganese sulfate, we observed significant reduction of quantity of cis-linoleic acid (C18:2) relative to the control medium and medium with sulfate of manganese or zinc respectively. But the total sum of unsaturated fatty acids wasn't changed (table 2).

So, the presence of manganese citrate, zinc citrate or zinc sulfate in media promotes to increase the content of total lipids approximately twice and modifies the fatty acids composition. In that time, manganese sulfate has no effect on the amount of total lipids, but modifies the fatty acids composition, too.

\section{Acknowledgements}

We are grateful to professor V.G. Kaplunenko (Institute of Nanobiotechnologies and Resource Conservation of Ukraine, Kiev) for synthesizing and providing zinc and manganese citrate.

\section{Conclusion}

Our results demonstrate, that biological activity of manganese citrate, in the case of accumulation of lipids, is higher than activity of manganese sulfate. Sulfates and citrates of investigated metals influence to different degrees on the amount of some amino acids in the mycelium of $T$. versicolor 353. Both citrates of zinc and manganese, more efficiently increases the quantity of L-serine and more substantially reduces the amount of L-lysine in mycelium relative to sulfate of these metals. Also citrates of both metals decrease amount of 
cis-linoleic acid (C18:2) relative to the control medium and media with sulfate of appropriate metals.

Thus, our investigations show that sulfates and citrates of studied metals have different effects on some biochemical parameters of biomass T. versicolor 353 .

\section{References}

AL-MAALI G.A. (2015). The influence of metal citrates obtained by aquananotechnology on growth of the strains of medical macromycetes Ganoderma lucidum 1900 and Trametes versicolor 353. Ukr. Bot. J., 72 (4): 393-397.

ANTONENKo L. A. (2013). Biotechnology of biomass higher basidiomycetes of the genus Coriolus: Cand. Sci. Diss. Abstract, Kyiv, 22 p. [Антоненко Л.А. (2013). Биотехнология получения биомассы высших базидиальных грибов рода Coriolus: автореф. дис. ... канд. биол. наук: спец. 03.00.20 «Биотехнология». Киев. 22 с.]

AOAC (1995). Official methods of analysis (16 ${ }^{\text {th }}$ ed.) Arlighton, VA; Association of Official Analytical Chemists.

Broadley M. R., White P. J., Hammond J. P., Zelko I., LuX A. (2007). Zinc in plants. New Phytologist 173 (4): 677-702.

Buchalo A.S., Mytropolska N.Yu., Mykchaylova O.B. (2011). Catalogue of the culture collection of mushrooms IBK. Alterpress, Kiev, $100 \mathrm{p}$.

Cai X., Pi Y., Zhou X., Tian L., Qiao S., \& Lin J. (2010). Hepatoma cell growth inhibition by inducing apoptosis with polysaccharide isolated from Turkey tail medicinal mushroom, Trametes versicolor (L.: Fr.) Lloyd (Aphyllophoromycetideae). International Journal of Medicinal Mushrooms, 12 (3): 257-263.

Christie WW (1989). Gas Chromatography and Lipids: A Practical Guide. Ayr: The Oily Press Ltd.

HeNDERSON J.W., Ricker R.D., BidLINGMEYER B.A., WoOdWARD C. (2000). Rapid, Accurate, Sensitive, and Reproducible HPLC Analysis of Amino Acids Amino Acid Analysis Using Zorbax Eclipse-AAA Columns and the Agilent. Agilent Technologies.

JÁmbor A., MolnÁR-Perl I. (2009a). Amino acid analysis by high-performance liquid chromatography after derivatization with 9-fluorenylmethyloxycarbonyl chloride. Literature overview and further study. Journal of Chromatography A, 1216: 3064-3077.

JÁmbor A., MolnÁr-Perl I. (2009b). Quantitation of amino acids in plasma by high performance liquid chromatography: Simultaneous deproteinization and derivatization with 9fluorenylmethyloxycarbonyl chloride. Journal of Chromatography A, 1216: 6218-6223.

KuAN Y. C., Wu Y. J., Hung C. L., \& SHEU F. (2013). Trametes versicolor protein YZP activates regulatory B lymphocytes-gene identification through de novo assembly and function analysis in a murine acute colitis model. PloS one, $\mathbf{8}(9)$.

Maehara Y., Tsujitani S., Saeki H., Oki E., Yoshinaga K., Emi Y., ... \& Baba H. (2012). Biological mechanism and clinical effect of protein-bound polysaccharide K (KRESTIN $®$ ): review of development and future perspectives. Surgery today, 42 (1): 8-28.

Manirakiza P., Covaci A., Schepens P. (2001). Comparative Study on Total Lipid Determination using Soxhlet, Roese-Gottlieb, Bligh \& Dyer, and Modified Bligh \& Dyer Extraction Methods. Journal of Food Composition and Analysis, 14: 93-100.

Patel S., Goyal A. (2012). Recent developments in mushrooms as anti-cancer therapeutics: a review. 3 Biotech., 2 (1): 1-15.

Soden D.M., Dobson A.D. (2001). Differential regulation of laccase gene expression in Pleurotus sajor-caju. Microbiology, 147 (7): 1755-1763.

Standish L.J., Wenner C.A., Sweet E.S., Bridge C., Nelson A., Martzen M., ... \& Torkelson, C. (2008). Trametes versicolor mushroom immune therapy in breast cancer. Journal of the Society for Integrative Oncology, 6 (3): 122-128.

Vasina, D.V., Mustafaev, O.N., Moiseenko, K.V., Sadovskaya, N. S., Glazunova, O.A., Tyurin, A.A., ... \& Koroleva, O.V. (2015). The Trametes hirsuta 072 laccase multigene family: Genes identification and transcriptional analysis under copper ions induction. Biochimie, 116: 154-164.

XiAO, J.H., ChEN, D.X., WAN, W.H., Hu, X.J., QI, Y., \& LIANG, Z.Q. (2006). Enhanced simultaneous production of mycelia and intracellular polysaccharide in submerged cultivation of Cordyceps jiangxiensis using desirability functions. Process biochemistry, 41 (8): 1887-1893.

ZHI-LING C. (2009). Effect of Some Trace Elements and Vitamins on Contents of Polysaccharide and Acid of Ganoderma lucidum [J]. Journal of Anhui Agricultural Sciences, 5: 078.

ZONG A., CAO H., WANG F. (2012). Anticancer polysaccharides from natural resources: A review of recent research. Carbohydrate Polymers, 90 (4): 1395-1410. 
Zou X. (2005). Effects of Zn supplementation on the growth, amino acid composition, polysaccharide yields and anti-tumour activity of Agaricus brasiliensis. World Journal of Microbiology and Biotechnology, 21 (3): 261-264.

Рекомендує до друку

Отримано 12.01.2016

О.С. Ходосовцев

Aдреси авторів:

Г.А. Аль-Маалі

Н.А. Бісько

Інститут ботаніки імені М.Г. Хлодного НАНУ

вул. Велика Житомирська, 28

м. Київ, 01601

Україна

galeb.almaali@gmail.com

A.M. Ocmanчyк

Інститут мікробіологї та вірусологї імені Д.К.

Заболотного НАН Украӥни

вул. Академіка Заболотного, 154

м. Киї, 03680

Украӥна

Authors' addresses:

G.A. Al-Maali

N.A. Bisko

Kholodny Institute of Botany NAS of Ukraine

2, Tereshchenkivska st.

01601, Kyiv

Ukraine

galeb.almaali@gmail.com

A.M. Ostapchuk

Zabolotny Institute of Microbiology and Virology NAS

of Ukraine

154, Acad. Zabolotny str.

Kyiv, 03680

Ukraine 